\title{
The Meaning of Title VII
}

$T$

HE JULY ISSUE OF News and Reports* describing more than 80 Title VII grants comes as a reminder that almost two years of research on the new educational media under the National Defense Education Act is now behind us. What has Title VII accomplished? How is it influencing education? Where is it taking us?

As far as tangible achievements are concerned, a large number of individual grants have been made for research, and many of the studies are at an advanced stage. We also have the contract program under Part B of Title VII which already has to its credit several important regional research conferences and a wide range of dissemination of research projects.

The effects of Title VII on education is a little more difficult to assess. Obviously we cannot separate the influence of this program from that exerted by Ford Foundation activities or by other on-going research programs. It is however apparent that Title VII has stimulated researchers to concentrate their efforts on discovering relationships of educational media to instruction, thereby alerting the entire educational field to the implications of technological developments. This was a trend started by the Ford Foundation several years ago with its fullscale attack on the educational television problem. Title VII appears to be broadening the influence to include a wider array of media applications.

Where is Title VII taking us? Here the answers are even less clear. At least in its grant program, Title VII is limited by its dependence

* Published by the New Educational Media Branch, Office of Education, U.S. Department of Health, Education, and Welfare. 
upon a system of voluntary project submission; the Office of Education cannot itself initiate the experimental study of necessary research. So it is not surprising to find almost half of the approved grants comparing the instructional effectiveness of the various media with conventional approaches to instruction. Nor is it surprising to note that about onethird of the grants have been made for the study of televised teaching. At the same time, an increase in the study of self-instructional approaches to learning and the production variables that lead to the design of these tools are a promising recent trend.

There remain as yet two significant gaps in the research coverage of the grant program, however. First, there is need for greater emphasis on the support of projects that investigate the application of total learning systems utilizing a variety of media combined in accordance with their unique instructional characteristics and for specific learning objectives. Second, some study is needed of factors relating to the administration and organization of education systems designed for the optimum use of all instructional media. Also worth considering is the fact that the possibilities of what may well be the most important instructional tool of all-the electronic computer-have as yet been almost completely ignored:

So the start that Title VII has made is encouraging. Its staff has been selflessly dedicated to the administration of the program. Hundreds of competent researchers are contributing to its success. The editors of AVCR wish to commend the Office of Education and the Advisory Committee on New Educational Media for their efforts in getting this difficult program in high gear.

William H. Allen, Editor 